Artikel Penelitian

\title{
Hubungan Pengetahuan dan Sikap Ibu Balita terhadap Tindakan Imunisasi Dasar Lengkap di Kelurahan Lambung Bukit Kota Padang Tahun 2014
}

\author{
Selvia Emilya ${ }^{1}$, Yuniar Lestari ${ }^{2}$, Asterina $^{3}$
}

\begin{abstract}
Abstrak
Program imunisasi dasar merupakan salah satu upaya untuk menurunkan angka kesakitan dan kematian pada bayi dan balita. Cakupan imunisasi dasar lengkap di Indonesia pada tahun 2010 menurun dibandingkan tahun 2007. Hal ini juga terjadi di provinsi Sumatera Barat, di kota Padang terjadi penurunan pada tahun 2012 dibandingkan tahun 2011. Kelurahan Lambung Bukit berada di wilayah kerja Puskesmas Pauh kota Padang terjadi Kejadian Luar Biasa campak sebanyak 54 kasus. Tujuan penelitian ini adalah untuk mengetahui hubungan pengetahuan dan sikap ibu balita terhadap tindakan imunisasi dasar di Kelurahan Lambung Bukit Kota Padang tahun 2014. Penelitian dilaksanakan di Kelurahan Lambung Bukit selama 10 bulan dari bulan Februari 2014 sampai Desember 2014, dengan menggunakan desain cross sectional. Jumlah sampel 40 orang dengan teknik pengambilan sampel random sampling. Pengumpulan data dilakukan melalui wawancara menggunakan kuesioner dan observasi. Analisis bivariat dilakukan dengan menggunakan uji chi-square dan fisher's exact test. Hasil penelitian didapatkan lebih dari separuh responden tidak memberikan imunisasi dasar lengkap pada anaknya, memiki pengetahuan rendah dan sikap positif mengenai imunisasi. Terdapat hubungan bermakna antara pengetahuan dan sikap ibu dengan pemberian imunisasi dasar lengkap di Kelurahan lambung Bukit. Petugas puskesmas agar memberikan penyuluhan tentang imunisasi.
\end{abstract}

Kata kunci: imunisasi dasar lengkap, pengetahuan, sikap

\begin{abstract}
Basic immunization program is an effort to reduce morbidity and mortality rate in infants and toddler. Complete basic immunization in Indonesia in 2010 decreased compared to 2007. This is also occured in the province of West Sumatera, in Padang there is also been a decreased from 2011 to 2012. Kelurahan Lambung Bukit in the area of Pauh Health Centre has 54 cases of measles. The objective of this study was to determine the relationship between knowledge and attitude of mothers on basic immunization in the village of Lambung Bukit in Padang in 2014. The research conducted in village Lambung Bukit for 10 months, from February 2014 until December 2014 by using cross sectional design. Total sample of 40 peoples with random sampling. Data collected through interviews using questionnaires and observation. Bivariate analyze with chi-square test and fisher exact test. The results showed that more than half of the respondents did not provide complete basic immunization in children, have low knowledge, and positive attitude toward immunization. There is a significant correlation between knowledge and attitude of mothers with complete basic immunization in the village of Lambung Bukit in Padang in 2014. Health care personal is hoped to provide conseling about immunization.
\end{abstract}

Keywords: complete basic immunization, knowledge, attitude

Affiliasi penulis: 1. Prodi Profesi Dokter FK Unand (Fakultas Kedokteran Universitas Andalas Padang), 2. Bagian IImu Kesehatan Masyarakat FK Unand, 3. Bagian Kimia FK Unand
Korespondensi: Selvia Emilya, Email:

emilyaselvia@gmail.com,Telp:082174504806 


\section{PENDAHULUAN}

Imunisasi merupakan salah satu upaya untuk merangsang sistim imunologi tubuh untuk membentuk antibodi (kekebalan) yang spesifik sehingga dapat melindungi tubuh dari serangan (Penyakit yang Dapat Dicegah Dengan Imunisasi, PD3I). ${ }^{1}$ Kepercayaan dan perilaku kesehatan ibu juga hal yang penting karena akan mempengaruhi status imunisasi anak. ${ }^{2}$

Pembangunan kesehatan mengutamakan upaya promotif dan preventif seperti program imunisasi yang terbukti sangat efektif untuk menurunkan angka kesakitan, kecacatan dan kematian akibat PD3I. Secara global, diperkirakan 2- 3 juta kematian per tahunnya berhasil dicegah karena penyakit difteri, campak, pertusis, polio melalui imunisasi, tetapi masih ada sekitar 22 juta bayi di dunia yang belum mendapat imunisasi lengkap dan sebesar 9,5 juta adalah di wilayah Asia Tenggara, termasuk didalamnya Indonesia. Situasi ini yang mendorong langkah global dalam meningkatkan kesadaran masyarakat dunia melalui pelaksanaan imunisasi. $^{3}$

Cakupan imunisasi di Indonesia pada tahun 2010 yaitu, BCG 77,9\%, Campak 74,4\%, Polio 66,7\%, DPT-HB 61,9\%. Persentase ini menurun jika dibandingkan dengan cakupan imunisasi tahun 2007 yaitu BCG $86,9 \%$, campak $81,6 \%$, Polio $71,0 \%$, DPTHB $62,8 \%$. Pencapaian cakupan imunisasi di Sumatera Barat pada tahun 2010 menurun dibandingkan tahun 2007. Pada tahun 2010 untuk BCG $71,8 \%$, Polio $63,5 \%$, DPT-HB 51,0\%, Campak $66,3 \%$, sedangkan pada tahun 2007 untuk BCG 83,1\%, Polio 69,4\%, DPT-HB 67,9\%, Campak 75,4\%. ${ }^{4}$ Menurut laporan Dinas Kesehatan Kota Padang, persentase cakupan imunisasi tahun 2012 menurun dibandingkan tahun 2011. Persentase cakupan imunisasi tahun 2012 untuk BCG 94,7\%, Polio 92,5\%, DPT-HB 91,4\%, Campak 88,0\%, sedangkan pada tahun 2011 untuk BCG 96,9\%, Polio 93,1\%, DPT-HB $91,7 \%$, Campak $88,1 \%{ }^{5}$

Perilaku kesehatan adalah semua aktivitas atau kegiatan seseorang yang dapat diamati (observable) maupun yang tidak dapat diamati (unobservable).
Perilaku kesehatan mengacu kepada 3 hal yaitu pengetahuan, sikap dan tindakan. ${ }^{6}$ Penelitian Hindun tahun 2009 menemukan pengetahuan dan sikap lbu mempunyai hubungan yang bermakna dengan status imunisasi dasar pada balita. Ibu yang berpengetahuan baik menunjukkan cakupan imunisasi dasar lengkap yang lebih tinggi pada anaknya dibandingkan ibu yang berpengetahuan rendah. Ibu yang memiliki sikap positif juga menunjukkan cakupan imunisasi dasar lengkap yang lebih tinggi pada anaknya dibandingkan ibu yang memiliki sikap negatif. ${ }^{7}$

Laporan tahunan di Puskesmas Pauh, terdapat peningkatan kasus campak pada tahun 2012. Pada tahun 2011, angka kejadian TBC 54 kasus dan tidak terdapat kasus Polio, Difteri, Pertusis, Tetanus, Hepatitis dan Campak. Pada tahun 2012, angka kejadian TBC 27 kasus, Hepatitis 4 kasus, Campak 54 kasus dan tidak terdapat kasus Polio, Difteri, Pertusis dan Tetanus. ${ }^{8}$

Kelurahan Lambung Bukik merupakan salah satu kelurahan yang berada di wilayah kerja Puskesmas Pauh. Pada kelurahan ini, ditemukan penyakit campak sebanyak 54 kasus pada bulan Desember 2012, sehingga Pemerintah Kota Padang menetapkan kelurahan itu sebagai Kejadian Luar Biasa (KLB). Menurut keterangan petugas kesehatan Puskesmas Pauh, kejadian ini disebabkan karena kurangnya kesadaran Ibu balita disana untuk mengimunisasikan anaknya. ${ }^{9}$ Survey yang dilakukan terhadap 10 orang Ibu balita, 6 orang mengatakan tidak mengetahui pentingnya imunisasi, 5 orang mengatakan bahwa imunisasi dapat menyebabkan anak meninggal/ cacat serta berkembangnya mitos bahwa imunisasi haram.

Berdasarkan latar belakang di atas, maka perlu diteliti hubungan pengetahuan dan sikap ibu balita terhadap tindakan imunisasi dasar di Kelurahan Lambung Bukik kota Padang tahun 2014.

\section{METODE}

Jenis penelitian ini adalah analitik dengan desain cross-sectional. Penelitian dilakukan pada Ibu di Kelurahan Lambung Bukit wilayah kerja Puskesmas 
Pauh Kota Padang yang dilaksanakan pada bulan Februari 2014 sampai Desember 2014.

Subjek pada penelitian ini adalah ibu yang memiliki bayi berusia 1 - 2 tahun di Kelurahan Lambung Bukit. Subjek dipilih secara random sampling dari tiga posyandu. Variabel bebas pada penelitian ini adalah pengetahuan dan sikap dan variabel terikat adalah tindakan imunisasi dasar lengkap. Instrumen penelitian menggunakan kuesioner dan pemantauan KMS/KIA.

\section{HASIL}

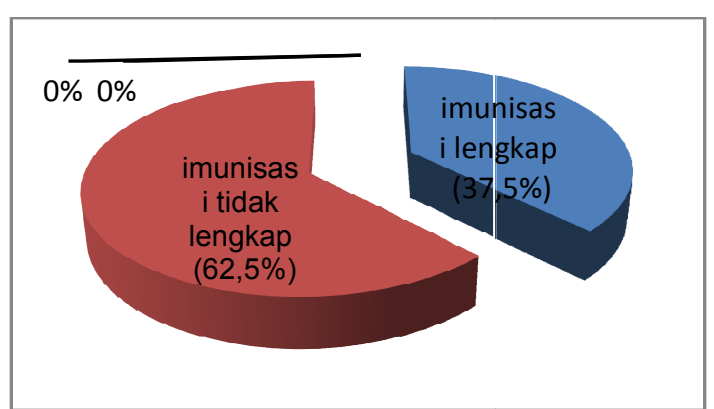

Gambar 1. Distribusi frekuensi pemberian imunisasi dasar lengkap pada bayi di Kelurahan Lambung Bukit Tahun 2014

Pada Gambar 1 menunjukkan lebih dari separuh responden tidak mengimunisasikan bayinya secara lengkap yaitu sebanyak $62,5 \%$.

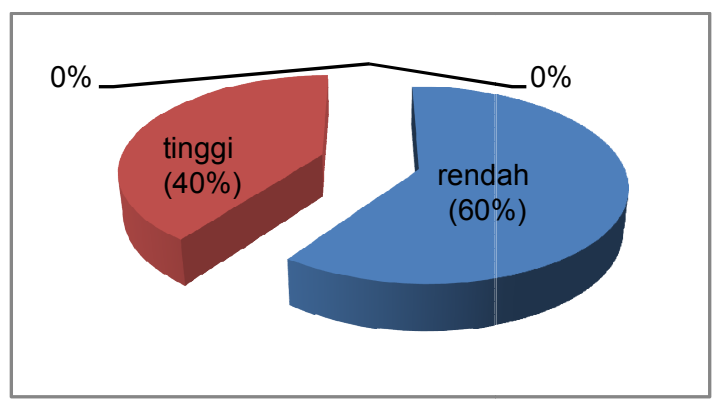

Gambar 2. Distribusi frekuensi menurut pengetahuan responden tentang pemberian imunisasi dasar lengkap di Kelurahan Lambung Bukit Tahun 2014

Gambar 2 menunjukkan lebih dari separuh responden memiliki pengetahuan yang rendah tentang imunisasi dasar lengkap yaitu sebanyak $60 \%$.
Tabel 1. Distribusi frekuensi pengetahuan responden menurut pertanyaan penelitian tentang pemberian imunisasi dasar lengkap pada bayi di Kelurahan Lambung Bukit tahun 2014

\begin{tabular}{|c|c|c|c|}
\hline \multirow[t]{2}{*}{ No } & \multirow[t]{2}{*}{ Kuesioner } & \multicolumn{2}{|c|}{ Menjawab benar } \\
\hline & & $f$ & $\%$ \\
\hline 1 & Definisi imunisasi & 28 & 70 \\
\hline 2 & Manfaat imunisasi & 16 & 40 \\
\hline 3 & $\begin{array}{l}\text { Akibat bayi tidak diberi } \\
\text { imunisasi }\end{array}$ & 12 & 30 \\
\hline 4 & Jenis imunisasi & 40 & 100 \\
\hline 5 & $\begin{array}{ll}\text { Waktu } & \text { mulai } \\
\text { mengimunisasi }\end{array}$ & 25 & 62,5 \\
\hline 6 & $\begin{array}{ll}\text { Frekuensi } & \text { pemberian } \\
\text { Hepatitis B-0 } & \end{array}$ & 13 & 32,5 \\
\hline 7 & $\begin{array}{l}\text { Frekuensi pemberian } \\
\text { BCG }\end{array}$ & 19 & 47,5 \\
\hline 8 & $\begin{array}{l}\text { Frekuensi pemberian } \\
\text { DPT-HB }\end{array}$ & 13 & 32,5 \\
\hline 9 & $\begin{array}{l}\text { Frekuensi pemberian } \\
\text { Polio }\end{array}$ & 16 & 40 \\
\hline 10 & $\begin{array}{l}\text { Frekuensi pemberian } \\
\text { Campak }\end{array}$ & 28 & 70 \\
\hline 11 & Fungsi imunisasi BCG & 19 & 47,5 \\
\hline 12 & Fungsi imunisasi DPT & 10 & 25 \\
\hline 13 & Bentuk imunisasi polio & 18 & 45 \\
\hline 14 & Usia pemberian campak & 23 & 57,5 \\
\hline 15 & Efek samping imunisasi & 23 & 57,5 \\
\hline
\end{tabular}

Tabel 1 diatas menggambarkan tingkat pengetahuan Ibu berdasarkan pertanyaan yang disajikan. Didapatkan adanya beberapa pertanyaan yang sedikit terjawab oleh responden.

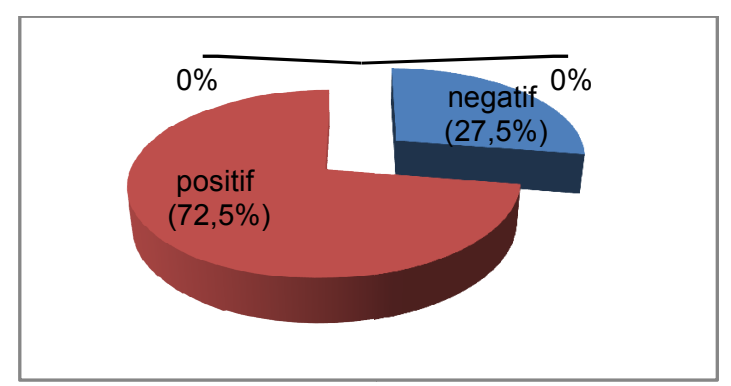

Gambar 3. Distribusi frekuensi berdasarkan sikap responden tentang pemberian imunisasi dasar lengkap di Kelurahan Lambung Bukit Tahun 2014 
Gambar 3 menunjukkan lebih dari separuh responden memiliki sikap positif tentang imunisasi dasar lengkap yaitu sebanyak $72,5 \%$.

Tabel 2. Hubungan pengetahuan ibu dengan pemberian imunisasi dasar lengkap pada bayi di Kelurahan Lambung Bukit tahun 2014

\begin{tabular}{|c|c|c|c|c|c|c|c|}
\hline \multirow{4}{*}{$\begin{array}{l}\text { Tingkat } \\
\text { Pengeta } \\
\text { huan }\end{array}$} & \multicolumn{4}{|c|}{ Pemberian Imunisasi } & \multirow{3}{*}{\multicolumn{2}{|c|}{ Total }} & \multirow{4}{*}{ p } \\
\hline & & Dasar & engl & & & & \\
\hline & \multicolumn{2}{|c|}{$\begin{array}{c}\text { Tidak } \\
\text { Lengkap }\end{array}$} & \multicolumn{2}{|c|}{ Lengkap } & & & \\
\hline & $f$ & $\%$ & $f$ & $\%$ & $f$ & $\%$ & \\
\hline Rendah & 21 & 87,5 & 3 & 12,5 & 24 & 100 & \\
\hline Tinggi & 4 & 25 & 12 & 75 & 16 & 100 & 0,001 \\
\hline Jumlah & 25 & 62,5 & 15 & 37,5 & 40 & 100 & \\
\hline
\end{tabular}

Tabel 2 menunjukkan adanya hubungan yang bermakna antara pengetahuan ibu dengan pemberian imunisasi dasar lengkap pada bayi.

Tabel 3. Hubungan sikap ibu dengan pemberian imunisasi dasar lengkap pada bayi di Kelurahan Lambung Bukit tahun 2014

\begin{tabular}{|c|c|c|c|c|c|c|c|}
\hline \multirow{3}{*}{ Sikap } & \multicolumn{4}{|c|}{$\begin{array}{l}\text { Pemberian Imunisasi } \\
\text { Dasar Lengkap }\end{array}$} & \multirow{2}{*}{\multicolumn{2}{|c|}{ Total }} & \multirow{3}{*}{ p } \\
\hline & \multicolumn{2}{|c|}{$\begin{array}{c}\text { Tidak } \\
\text { Lengkap }\end{array}$} & \multicolumn{2}{|c|}{ Lengkap } & & & \\
\hline & $f$ & $\%$ & $f$ & $\%$ & $f$ & $\%$ & \\
\hline Negatif & 11 & 100 & 0 & 0 & 11 & 100 & \\
\hline Positif & 14 & 48,3 & 15 & 51,7 & 29 & 100 & 0,003 \\
\hline Jumlah & 25 & 62,5 & 15 & 37,5 & 40 & 100 & \\
\hline
\end{tabular}

Pada Tabel 3 terlihat adanya hubungan yang bermakna antara sikap ibu dengan pemberian imunisasi dasar lengkap pada bayi.

\section{PEMBAHASAN}

Berdasarkan hasil penelitian ini diketahui 25 dari 40 responden $(62,5 \%)$ tidak mengimunisasikan bayinya secara lengkap. Penelitian Muhammad pada tahun 2003 mengatakan bahwa tindakan ibu yang tidak bekerja dalam mengimunisasikan bayinya adalah kurang. Faktor yang mempengaruhi pemberian imunisasi dasar lengkap adalah pengetahuan, pendidikan, usia ibu, sikap, status sosial ekonomi. ${ }^{2}$

Sebanyak 24 dari 40 responden (60\%) memiliki pengetahuan yang rendah tentang imunisasi dasar lengkap. Banyak pertanyaan dalam kuesioner tentang pemberian imunisasi dasar lengkap yang kurang dari $60 \%$ ibu yang menjawab dengan benar. Pertanyaan tersebut adalah mengenai manfaat imunisasi, akibat bayi tidak diberi imunisasi, frekuensi pemberian hepatitis B-0, BCG, DPT-HB, Polio, fungsi imunisasi BCG, DPT, bentuk pemberian Polio, usia pemberian campak dan efek samping imunisasi.

Hasil penelitian ini sejalan dengan penelitian Muhammad pada tahun 2003 yang menunjukkan bahwa tingkat pengetahuan responden tentang imunisasi masih buruk meskipun pendidikan responden mayoritas tamat SMA. ${ }^{2}$ Hal ini mungkin dikarenakan oleh pengalaman responen tentang imunisasi masih buruk. Pengalaman juga merupakan sumber pengetahuan. ${ }^{10}$

Berdasarkan hasil penelitian diketahui sebanyak 29 dari 40 responden $(72,5 \%)$ memiliki sikap yang positif tentang imunisasi dasar lengkap. Hasil penelitian ini sejalan dengan penelitian Hindun tahun 2009 di wilayah kerja Puskesmas Swakelola Gandus Palembang. ${ }^{7}$ Sikap merupakan respon seseorang yang masih tertutup terhadap suatu stimulus atau objek. Pengetahuan, pikiran, keyakinan, dan emosi memegang peranan penting dalam penentuan sikap seseorang. ${ }^{11}$

Pada hasil penelitian ini didapatkan bahwa pemberian imunisasi dasar lengkap lebih besar persentasenya pada ibu dengan tingkat pengetahuan yang tinggi (75\%) dibandingkan dengan yang berpengetahuan rendah (12,5\%). Pemberian imunisasi dasar lengkap lebih banyak pada ibu yang sikap positif $(51,7 \%)$ dibandingkan dengan yang bersikap negatif $(0 \%)$. Hasil uji statistik didapatkan hubungan yang bermakna antara pengetahuan dan sikap ibu dengan pemberian imunisasi dasar lengkap.

Hasil penelitian ini didukung oleh penelitian Arvitarius tahun 2012 di Desa Karanganyar Kecamatan Poncokusumo Kabupaten Malang. ${ }^{12}$ Hasil ini juga sesuai dengan pendapat dalam buku Notoatmodjo tahun 2012 yang menyatakan bahwa adanya kecenderungan seseorang yang berpengetahuan tinggi untuk berperilaku baik dalam bidang kesehatan, dalam hal ini berperilaku mengimunisasikan anaknya, dan sebaliknya. ${ }^{11}$ 
Secara teori memang perubahan perilaku melalui proses perubahan pengetahuan-sikaptindakan. Namun beberapa penelitian membuktikan bahwa proses tersebut tidak selalu ada dalam teori. Seseorang telah berperilaku positif meskipun pengetahuan dan sikapnya masih negatif. Ibu yang memiliki sikap positif juga menunjukkan cakupan imunisasi dasar lengkap yang lebih tinggi pada anaknya dibandingkan ibu yang memiliki sikap negatif. $^{10}$

\section{SIMPULAN}

Terdapat hubungan antara pengetahuan dan sikap ibu dengan pemberian imunisasi dasar lengkap pada balita di Kelurahan lambung Bukit kota Padang.

\section{DAFTAR PUSTAKA}

1. Dinas Kesehatan Provinsi Sumatera Barat. Pointer program imunisasi di provinsi Sumatera Barat. Padang: Dinas Kesehatan Sumatera Barat; 2012.

2. Muhammad A. Pengetahuan, sikap dan perilaku ibu tidak bekerja tentang imunisasis (tesis). Medan: Fakultas Kedokteran Universitas Sumatera Utara; 2003.

3. Kementerian Kesehatan RI. Profil kesehatan Indonesia tahun 2013. Jakarta: Departemen Kesehatan RI; 2013.
4. Badan Penelitian dan Pengembangan Kesehatan. Laporan hasil riset kesehatan dasar (Riskesdas) Indonesia tahun 2010. Jakarta: Departemen Kesehatan RI; 2011.

5. Dinas Kesehatan Kota Padang. Laporan tahunan 2012. Padang: Dinas Kesehatan Kota Padang; 2013

6. Notoatmodjo S. Promosi kesehatan teori dan aplikasinya. Jakarta: Rineka Cipta; 2010.

7. Hindun S. Hubungan antara pengetahuan dan sikap ibu dengan status kelengkapan imunisasi dasar pada balita di wilayah kerja puskesmas Swakelola Gandus Palembang tahun 2009 (skripsi). Palembang: Politeknik Kesehatan Palembang; 2009.

8. Puskesmas Pauh. Laporan program imunisasi 2011. Padang: Puskesmas Pauh; 2012.

9. Puskesmas Pauh. Laporan program imunisasi 2012. Padang: Puskesmas Pauh; 2013.

10. Notoatmodjo S. Kesehatan masyarakat ilmu dan seni. Jakarta:Rineka Cipta; 2011.

11. Notoatmodjo S. Promosi kesehatan dan perilaku kesehatan. Jakarta: Rineka Cipta; 2012.

12. Arvitarius. Hubungan pengetahuan dan sikap ibu tentang pemberian imunisasi pada bayi (0-11 bulan) di Desa Karanganyar Kecamatan Poncokusumo Kabupaten malang (skripsi). Malang: Fakultas Kedokteran Universitas Brawijaya; 2012. 